\title{
PENGARUH KOMPENSASI TERHADAP \\ KINERJA KARYAWAN \\ DI KAMPUNG BATU MALAKASARI TEKTONA WATERPARK KABUPATEN BANDUNG
}

\author{
Nova Riana 1 \\ STIEPAR YAPARI, Bandung \\ nova.riana@ymail.com \\ Khoirul Fajri $^{2}$ \\ STIEPAR YAPARI, Bandung \\ khoirul.fajri@yahoo.com \\ Karin Alsyaumi $^{3}{ }^{3}$ \\ STIEPAR YAPARI, Bandung \\ karin_alsaumi@yahoo.com
}

\begin{abstract}
ABSTRAK
Imbalan atau kompensasi adalah faktor penting yang mempengaruhi bagaimana dan mengapa orang-orang bekerja pada suatu perusahaan dan bukan pada perusahaan yang lainnya. Perusahaan harus cukup kompetitif dengan beberapa jenis kompensasi untuk mempekerjakan, mempertahankan, dan memberi imbalan terhadap kinerja setiap individu di dalam organisasinya.

Tujuan penelitian ini untuk mengetahui pengaruh kompensasi terhadap kinerja karyawan. Metode penelitian yang digunakan adalah metode kuantitatif (regresi berganda) dengan analisis deskriptif dan verifikatif, dengan penggunaan sampel untuk pengumpulan data melalui penyebaran kuesioner kepada 30 responden. Hasil penelitian deskriptif menyatakan bahwa kompensasi langsung dalam kategori baik, kompensasi tidak langsung dalam kategori baik, dan kinerja dalam kategori baik. Sedangkan hasil analisis verifikatif menyatakan bahwa pengaruh kompensasi terhadap kinerja karyawan sebesar 0,619 atau $61.90 \%$ dan signifikan.
\end{abstract}

Kata Kunci: Kompensasi, Kinerja.

\section{THE EFFECT OF COMPENSATION THROUGH EMPLOYEES' PERFORMANCE AT BATU MALAKASARI TEKTONA VILLAGE WATERPARK BANDUNG DISTRICT}

\author{
ABSTRACT \\ Remuneration or compensation is an important factor that affect how and \\ why people work in a organization and not on other organizations. Companies
}


must be competitive with some kind of compensation to hire, retain, and reward the performance of each individual in the organization.

The purpose of this study is to determine the effect of compensation on employee working performance. Method of this research is descriptive and verification method, with 30 respondents as samples for data collection via questionnaires. The result of descriptive analysis on this research shows that the category of direct compensation is good, the indirect compensation in good category, and the working performance is in good category as well. Whilst the result of verificative analysis shows that the overall compensation influenced working performance of the employees by 0,619 or 61,90\%, considered significant.

Keywords: Compensation, Working Performance

\section{PENDAHULUAN}

Keberadaan sumber daya manusia di dalam suatu perusahaan memegang peranan sangat penting karena tenaga kerja memiliki peran yang besar untuk menjalankan aktivitas perusahaan. Potensi setiap sumber daya manusia yang ada dalam perusahaan harus dapat dimanfaatkan dengan sebaik-baiknya agar mampu memberikan output optimal. Kinerja karyawan merupakan suatu hal yang sangat penting dalam usaha organisasi untuk mencapai tujuannya. Oleh karena itu salah satu cara terbaik untuk meningkatkan kualitas kinerja karyawan adalah dengan menghubungkan kompensasi dengan kinerja karyawan. Di dalam sebuah perusahaan, kinerja karyawan dituntut dalam upaya memajukan organisasi perusahaan tersebut. Salah satu indikator keberhasilan perusahaan adalah kinerja yang baik. Tercapainya tujuan perusahaan tidak hanya tergantung pada aspek fisik seperti peralatan modern, sarana dan prasarana yang lengkap, tetapi justru lebih tergantung pada sumber daya manusia yang melaksanakan pekerjaan tersebut. Keberhasilan suatu organisasi sangat dipengaruhi oleh kinerja individu karyawannya. Setiap organisasi maupun perusahaan akan selalu berusaha untuk meningkatkan kinerja karyawan, dengan harapan apa yang menjadi tujuan perusahaan akan tercapai.

Kompensasi memegang peranan penting dalam meningkatkan kinerja karyawan karena salah satu alasan utama seseorang bekerja adalah untuk memenuhi kebutuhan hidupnya dari imbalan yang mereka terima dari bekerja. Menurut Hasibuan (2012:118) kompensasi adalah semua pendapatan yang berbentuk uang, barang langsung, atau tidak langsung yang diterima karyawan sebagai imbalan atas jasa yang diberikan kepada perusahaan. Salah satu tujuan pemberian kompensasi adalah — pemberian kompensasi yang memadai adalah suatu penghargaan terhadap prestasi kerja para . Hal tersebut selanjutnya akan mendorong kinerja sesuai yang diinginkan organisasill (Sedarmayanti 2009:2004) atau dapat disebut juga menghargai prestasi kerja. Suatu instansi atau perusahaan harus dapat menentukan sistem kompensasi yang sesuai dengan kemampuannya 
supaya karyawan yakin dan mengerti bahwa apa yang mereka terima telah telah sesuai dengan apa yang mereka kerjakan, maka karyawan akan termotivasi dalam bekerja. Sedangkan bila kompensasi tidak memadai maka kepuasan kerja, motivasi dan kinerja karyawan akan menurun.

Dari penelitian terdahulu, peneliti mendapati bahwa Zubair, Ali and Arslan (2014) yang juga meneliti pengaruh kompensasi terhadap kinerja memperoleh hasil penelitian bahwa - It is founded from different results that Compensation has positive impact on employee performance. Tinjauan atas penelitian terdahulu lainnya tentang pengaruh kompensasi terhadap motivasi, komitmen dan kinerja dari Rizal, Idrus, Djumahir, Mintarti (2014) memperlihatkan hasil sebagai berikut: - This study results indicate that compensation has significant effect on motivation and organizational commitment, but does not have significant effect on employee performance. Organizational commitment and motivation have significant effect on employee's performance, as well as a significant effect of organizational commitment on employee performance. Penelitian sejenis lainnya dari Qureshi and Sajjad (2015) memperlihatkan bahwa - compensation to the employees should be paid attention to, which would result in enhanced job performance and conflict free work-family environmentll.

Menurut Hasibuan (2012:10), IManajemen sumber daya manusia (MSDM) adalah ilmu dan seni mengatur hubungan dan peranan tenaga kerja agar efektif dan efisien membantu terwujudnya suatu perusahaan, karyawan dan masyarakat. Sedangkan menurut Mangkunegara (2013:2) bahwa: -Manajemen sumber daya manusia merupakan suatu perencanaan, pengkoordinasian, pelaksanaan, dan pengawasan terhadap pengadaan, pengembangan, pemberian balas jasa, pengintegrasian, pemeliharaan, dan pemisahan tenaga kerja dalam rangka mencapai tujuan organisasill. Pengertian lain dari Eddy Sutrisno (2015:5) mengatakan bahwa: Manajemen sumber daya manusia merupakan bidang strategis dari organisasi. Manajemen sumber daya manusia harus dipandang sebagai perluasan dari pandangan tradisional untuk mengelola orang secara efektif dan untuk itu membutuhkan pengetahuan tentang perilaku manusia dan kemampuan pengelolanya. Sementara itu, Edwin B. Flippo dalam Sedarmayanti (2009:5) mengemukakan bahwa: Manajemen sumber daya manusia adalah perencanaan, pengorganisasian, pengarahan, dan pengawasan kegiatan-kegiatan, pengadaan, pengembangan, pemberian kompensasi, pengintegrasian, pemeliharaan, dan pelepasan sumber daya manusia, agar tercapai berbagai tujuan individu, organisasi dan masyarakat.

Dari beberapa pengertian di atas dapat diperoleh pemahaman bahwa manajemen sumber daya manusia mempunyai definisi sebagai suatu perencanaan, pengorganisasian, pengarahan dan pengawasan atas pengadaan, pengembangan, pemberian balas jasa (kompensasi), pengintegrasian, pemeliharaan dan pemutusan hubungan kerja dengan maksud untuk mencapai tujuan organisasi suatu perusahaan.

Kegiatan Manajemen Sumber Daya Manusia merupakan aspek sentral dan merupakan rantai kunci dalam mencapai tujuan organisasi. Kegiatan Sumber 
Daya Manusia akan berjalan dengan lebih lancar bila memanfaatkan fungsi-fungsi manajemen. Adapun menurut Mangkunegara (2013:3) fungsi manajemen sumber daya manusia termaksud adalah sebagai berikut: (a) Perencanaan (Planning). Yaitu kegiatan memperkirakan atau menggambarkan dimuka tentang kerja, agar sesuai dengan kebutuhan organisasi secara efektif dan efisien dalam membantu terwujudnya tujuan. (b) Pengorganisasian (organizing), yaitu kegiatan untuk mengatur dengan menetapkan pembagian kerja, hubungan kerja, delegasi wewenang, integrasi dan koordinasi, dalam bentuk bagan organisasi. (c) Pengarahan (directing), yaitu kegiatan memberi petunjuk kepada, agar mau kerja sama dan bekerja efektif serta efisien dalam membantu tercapainya tujuan organisasi. (d) Pengendalian (controlling), yaitu kegiatan kegiatan mengendalikan mentaati peraturan organisasi dan bekerja sesuai dengan rencana. (e) Pengadaan (procurement), yaitu proses penarikan, seleksi, penempatan, orientasi, dan induksi untuk mendapatkan yang sesuai dengan kebutuhan organisasi.

Sementara itu, Hasibuan (2012:21) menyatakan bahwa fungsi manajemen sumber daya manusia meliputi perencanaan, pengorganisasian, pengarahan, pengendalian, pengadaan, pengembangan, kompensasi, pengintegrasian, pemeliharaan, kedisiplinan dan pemberhentian. Perencanaan adalah merencanakan tenaga kerja secara efektif serta efisien agar sesuai dengan kebutuhan perusahaan dalam membantu terwujudnya tujuan. Pengorganisasian adalah kegiatan untuk mengorganisasi semua karyawan dengan melakukan pembagian kerja, hubungan kerja, delegasi wewenang, integrasi, dan koordinasi dalam bagan organisasi. Pengarahan adalah kegiatan melakukan kegiatan mengarahkan semua karyawan, agar mau bekerja sama dan bekerja efektif serta efisien dalam membantu tercapainya tujuan perusahaan, karyawan, dan masyarakat. Pengendalian adalah kegiatan mengendalikan semua karyawan,agar mentaati peraturan-peraturan perusahaan dan bekerja sesuai dengan rencana. Pengadaan adalah proses penaikan, seleksi, penempatan, oriental dan induksi untuk mendapatkan karyawan yang sesuai dengan kebutuhan perusahaan. Pengembangan (development) adalah proses peningkatan keterampilan teknis, teoritis, konseptual, dan moral karyawan melalui pendidikan dan pelatihan. Kompensasi adalah pemberian balas jasa langsung (direct) dan tidak langsung (indirect), uang atau barang kepada karyawan sebagai imbalan jasa yang di berikan kepada perusahaan. Pengintegrasian adalah kegiatan untuk mempersatukan kepintangan perusahaan dan kebutuhan karyawan, agar tercipta kerja sama yang serasi dan saling menguntungkan. Pemeliharaan (maintenance) adalah kegiatan untuk memelihara atau meningkatkan kondisi fisik, mental dan loyalitas karyawan agar mereka tetap mau bekerja sama sampai pension. Kedisiplinan merupakan fungsi MSDM yang terpenting dan kunci terwujudnya tujuan karena tanpa disiplin yang baik sulit terwujud tujuan yang maksimal. Pemberhentian (separation) adalah putusnya hubungan kerja seseorang dari suatu perusahaan. Pemberhentian ini disebaban keinginan karyawan, keinginan perusahaan, kontrak kerja berakhir, pensiun dan sebab-sebab lainnya. 


\section{LANDASAN TEORI}

\section{Kompensasi}

Sedarmayanti (2010:239) menyatakan bahwa: "Kompensasi adalah segala sesuatu yang diterima oleh segala balas jasa untuk kerja mereka. Dalam suatu organisasi masalah kompensasi merupakan masalah yang sangat kompleks, namun penting bagi karyawan maupunorganisasi itu sendiri. Pemberian kompensasi bagi harus mempunyai dasar yang rasional, namun demikian faktor emosional dan prikemanusiaan tidak boleh diabaikan. Sedangkan Andrew E. Sikula dalam Mangkunegara (2011:83) menyatakan:

The process of wage or salary administration (or, "compensation" as it sometimes called) involves the weighing or balancing of accounts. A compensation is anything that constitutes or is regarder as an equivalent or recompense. In the employment world, financial rewards are the compensations resources provided to employees for the return of their services. The therms "remuneration", "wage", and "salary" also are used to describe this financial arrangement between employers and employees. A remuneration is a reward, payment, or reimbursement occasion also may be non-financial in nature. Remuneration are usually in the form of comprehensive pay concept than, are the ideas of salary and wage that normally include a financial but not a non-financial dimension".

Sedangkan Handoko dalam Eddy Sutrisno (2011:183) menjelaskan kompensasi adalah segala sesuatu yang diterima oleh karyawan sebagai balas jasa untuk kerja mereka. Dari beberapa pendapat di atas, peneliti merangkum pemahaman bahwa salah satu cara perusahaan untuk meningkatkan prestasi kerja, motivasi kerja adalah melalui kompensasi, sehingga kompensasi menjadi kunci pemecahan bagaimana membuat karyawan berbuat sesuai dengan keinginan organisasi perusahaan. Pada gilirannya, melalui kompensasi, perusahaan dapat mengembangkan dan mendesain program untuk memastikan bahwa perusahaan memberi imbalan atas perilaku dan hasil kinerja karyawan yang mendukung pencapaian tujuan organisasi.

Menurut Hasibuan (2012:121) tujuan pemberian kompensasi antara lain adalah: (a) Ikatan kerjasama. Dengan pemberian kompensasi terjalinlah ikatan kerjasama formal antara majikan dengan karyawan. Karyawan harus mengerjakan tugas-tugasnya dengan baik, sedangkan pengusaha wajib membayar kompensasi sesuai dengan perjanjian yang disepakati. (b) Kepuasan kerja. Dengan balas jasa, karyawan akan dapat memenuhi kebutuhan-kebutuhan fisik, status sosial sehingga memperoleh kepuasan kerja dari jabatannya. (c). Motivasi. Jika balas jasa yang diberikan cukup besar, manajer akan mudah memotivasi bawahannya. (d). Disiplin. Dengan pemberian balas jasa yang cukup besar, maka disiplin karyawan semakin baik. Mereka akan menyadari serta mentaati peraturan-peraturan yang berlaku.

Notoadmodjo dalam Eddy Sutrisno (2011:188) merinci tujuan kompensasi sebagai berikut: (a) Menghargai prestasi kerja. Pemberian kompensasi yang 
memadai adalah suatu penghargaan terhadap prestasi kerja para nya. Hal tersebut selanjutnya akan mendorong kinerja sesuai yang diinginkan organisasi. (b) Menjamin keadilan. Dengan adanya sistem kompensasi yang baik, akan menjamin adanya keadilan diantaranya dalam organisasi, masing-masing akan memperoleh imbalan yang sesuai dengan tugas, fungsi, jabatan, dan prestasi kerjanya. (c) Mempertahankan. Dengan sistem kompensasi yang baik, para akan lebih betah dan bertahan bekerja pada organisasi itu. Hal ini berarti mencegah keluarnya dari organisasi untuk mencari pekerjaan yang lebih menguntungkan. (d) Memperoleh yang bermutu. (d) Dengan sistem kompensasi yang baik akan menarik lebih banyak calon. Dengan banyaknya calon maka peluang untuk memilih yang bermutu akan lebih banyak. (e) Pengendalian biaya. Dengan sistem pemberian kompensasi yang baik akan mengurangi seringnya pelaksanaan rekrutmen, sebagai akibat dari makin seringnya yang keluar. Hal ini berarti penghematan biaya untuk rekrutmen dan seleksi calon karyawan baru.

Ada 2 (dua) sistem kompensasi menurut pendapat Hasibuan (2012:123124) yaitu sistem waktu dan sistem hasil: (a) Sistem waktu. Dalam sistem ini besarnya kompensasi (gaji dan upah) ditetapkan berdasarkan standar waktu seperti jam, minggu atau bulan. Sistem waktu biasanya ditetapkan jika prestasi kerja sulit diukur perunitnya dan bagi karyawan tetap kompensasinya dibayar atas sistem waktu secara periodik setiap bulannya. Besar kompensasi sistem waktu hanya didasarkan kepada lamanya bekerja bukan dikaitkan kepada prestasi kerjanya. (b) Sistem Hasil. Dalam sistem hasil ini, besarnya kompensasi yang dibayar selalu didasarkan kepada banyaknya hasil yang dikerjakan bukan kepada lamanya waktu mengerjakannya. Sistem hasil ini tidak dapat diterapkan kepada karyawan tetap.

Sebagai Indikator, ada dua bentuk kompensasi, yaitu bentuk langsung dan tidak langsung. Hal ini sesuai pernyataan Mangkunegara (2013:85-86) bahwa ada dua bentuk kompensasi yaitu: (a) Upah dan Gaji. Upah adalah pembayaran berupa uang untuk pelayanan kerja atau uang yang biasanya dibayarkan kepada secara per jam, per hari, per setengah hari. Sedangkan gaji merupakan uang yang dibayarkan kepada atas jasa pelayanannya yang diberikan secara bulanan. Prinsip upah dan gaji, yaitu tingkat bayaran, struktur bayaran, menentukan bayaran secara individu, metode pembayaran, dan kontrol pembayaran. Tingkat bayaran bisa diberikan tinggi, rata-rata atau rendah bergantung pada kondisi perusahaan. Artinya, tingkat pembayaran bergantung pada kemampuan perusahaan membayar jasa nya. Struktur pembayaran berhubungan dengan rata-rata bayaran, tingkat pembayaran, dan klasifikasi jabatan diperusahaan. Penentuan bayaran individu perlu didasarkan pada rata-rata tingkat bayaran, tingkat pendidikan, masa kerja dan prestasi kerja. Metode pembayaran, ada dua metode pembayaran yaitu metode pembayaran yang didasarkan pada waktu (per jam, per hari per minggu, per bulan). Kedua, metode pembayaran yang didasarkan pada pembagian hasil. Kontrol pembayaran merupakan pengendalian secara langsung dan tak langsung dari biaya kerja. Pengendalian biaya merupakan faktor utama dalam administrasi upah dan gaji. Tugas mengontrol pembayaran adalah pertama, mengembangkan standard kompensasi dan meningkatkan fungsinya. Kedua, mengukur hasil yang 
bertentangan dengan standar yang tetap. Ketiga, meluruskan perubahan standar pembayaran upah. (b) Benefit (keuntungan) dan pelayanan. Benefit adalah nilai keuangan (moneter) langsung untuk yang secara cepat dapat ditentukan. Sedangkan pelayanan adalah nilai keuangan (moneter) langsung untuk yang tidak dapat secara mudah ditentukan. Program benefit bertujuan untuk mengecilkan turnover, meningkatkan modal kerja, dan meningkatkan keamanan. Adapun kriteria program benefit adalah biaya, kemampuan membayar, kebutuhan, kekuatan kerja, tanggung jawab sosial, reaksi kekuatan kerja, dan relasi umum. Sedangkan program pelayanan adalah laporan tahunan untuk, adanya tim olahraga, kamar tamu, kafetaria , surat kabar perusahaan, bantuan hukum, fasilitas ruang baca dan perpustakaan, pemberian makan siang, adanya fasilitas medis, dokter perusahaan, tempat parkir, ada program rekreasi atau darmawisata. Menurut Handoko dalam Eddy Sutrisno (2011:183-184) dimensi kompensasi meliputi kompensasi langsung dan tidak langsung yaitu: (a) Kompensasi langsung meliputi: gaji/upah dan insentif. (b) Kompensasi tidak langsung meliputi : fasilitas kantor, asuransi, transportasi.

Kampung Batu Malakasari adalah salah satu destinasi wisata alam yang bernuansa budaya Sunda di Kabupaten Bandung, tepatnya di Desa Malakasari, Kecamatan Baleendah. Destinasi wisata ini berdiri sejak bulan Juni 2010 dengan luas \pm 5 Ha dan memiliki banyak kategori wisata, antara lain agrowisata, ekowisata dan geowisata sehingga disebut sebagai "Laboratorium Alam Pendidikan Lingkungan Hidup dan Budaya Sunda. Kampung Batu Malakasari merupakan daerah wisata alam yang menyajikan panorama alam yang potensinya berupa danau kecil yang mengelilingi oleh bebatuan alam. Selain itu, di sana juga terdapat peternakan sapi, kelinci, kambing, serta penangkaran rusa. Beberapa lahan pertanian seperti sawah dan kebun sayuran juga dapat ditemui di sana. Untuk tujuan Pendidikan Lingkungan Hidup dan Budaya Sunda, Kampung Batu Malakasari dilengkapi dengan beberapa wahana atau fasilitas sebagai sarana Laboratorium Alam yaitu: Wahana danau dan bukit batu, wahana persawahan, wahana perkebunan, wahana peternakan (sapi, domba, kambing, kelinci, unggas dan penangkaran rusa totol), wahana perikanan, wahana rumah adat Sunda, wahana tektona waterpark dan wahana flying fox outbond.

Dari wawancara awal dengan beberapa karyawan Kampung Batu Malakasari, diperoleh data yang mengemukakan bahwa terdapat kelemahan kinerja yang disebabkan oleh ketidakpuasan atas kompensasi, di mana kompensasi yang ada di Kampung Batu Malakasari Tektona Waterpark yaitu gaji yang tidak sesuai dengan Upah Minimum Regional Wilayah Setempat dan dalam waktu pemberian gaji sering terjadi keterlambatan.

\section{Kinerja}

Kinerja berasal dari kata job performance atau actual performance (prestasi kinerja atau prestasi sesungguhnya yang dicapai oleh seseorang). Menurut Anwar Prabu (2008:67) mendefinisikan kinerja (prestasi kerja) sebagai hasil kerja secara kualitas dan kuantitas yang dicapai oleh seseorang dalam melaksanakan tugasnya sesuai dengan tanggung jawab yang di berikan 
kepadanya. Menurut Sedarmayanti (2009:50) performance diterjemahkan menjadi kinerja, juga berarti prestasi kerja, pelaksanaan kerja, atau hasil kerja/unjuk kerja/penampilan kerja.

Menurut Vethzal (2009:548), "Kinerja merupakan perilaku nyata yang ditampilkan setiap orang sebagai prestasi kerja yang dihasilkan untuk karyawan sesuai dengan perannya dalam perusahaan. Sedangkan Menurut Benardin (2001:43) menyatakan bahwa "kinerja merupakan catatan hasil yang diproduksi (dihasilkan) atas fungsi pekerjaan tertentu atau aktifitas-aktifitas selama periode waktu tertentu". Pengertian lain dari John Miner dalam Sudarmanto (2015:8) menyatakan bahwa kinerja merupakan produktivitas hubungan antara jumlah barang dan jasa yang dihasilkan dengan jumlah tenaga kerja, modal, dan sumber daya yang digunakan dalam produksi itu.

Dari beberapa pendapat tersebut, dapat dipahami bahwa secara umum kinerja dapat diartikan sebagai produktivitas hubungan antara jumlah barang dan jasa yang dihasilkan dengan jumlah tenaga kerja, modal, dan sumber daya yang digunakan dalam produksi itu. Kemudian pada prinsipnya kinerja merupakan hasil kerja yang telah dicapai oleh didasarkan pada persyaratan -persyaratan yang harus dipenuhi dalam pekerjaan tersebut. Dengan demikian kinerja adalah pencapaian dan keluaran atau hasil pekerjaan yang sesuai dengan tuntunan dan rencana organisasi yang telah ditetapkan sebelumnya.

Penilaian kerja mengacu pada suatu sistem formal dan terstruktur yang digunakan untuk mengukur, menilai, dan mempengaruhi sifat-sifat yang berkaitan dengan pekerjaan, perilaku dan hasil nilai prestasi adalah hasil kerja karyawan dalam lingkup tanggung jawabnya. Kinerja dapat dinilai dari apa yang dilakukan oleh seseorang dalam kerjanya, sebagaimana yang dikemukakan oleh Leeham dan Wexley dalam Sedarmayanti (2009:65) sebagai berikut: Kinerja individu dapat dinilai dari apa yang dilakukan oleh individu tersebut dalam kerjanya. Dengan kata lain kinerja individu adalah bagaimana seseorang melaksanakan pekerjaannya atau unjuk kerja (job performance). Penilaian kinerja merupakan cara yang paling efektif dan biasanya digunakan saat menilai keberhasilan sumber daya manusia dalam mencapai tujuan. Masalah yang sering muncul dalam suatu organisasi pada saat menilai kinerja adalah penentuan standar kinerja yang tepat, penyampaian standar kepada bawahan, faktor-faktor yang diukur, frekuensi pengukuran dan alat-alat pengukuran yang digunakan. Kegunaan penilaian kinerja karyawan adalah: (a) Posisi tawar: melakukan negoisasi yang destinasitif dan rasional. (b) Perbaikan Kinerja: untuk memperbaiki kinnerja, manajer, dan supervisor dimasa yang akan datang. (c) Penyesuaian Kompensasi: untuk membantu dalam pengambilan keputusan penentuan siapa yang seharusnya menerima kenaikan pembayaran dalam bentuk upah, bonus, ataupun bentuk lainnya. (d) Keputusan Penempatan: untuk promosi, transfer, ataupun penurunan jabatan atau pangkat yang biasanya didasarkan pada kinerja masa lalu dan bersifat antisipatif. (e) Pelatihan dan Pengembangan: untuk melakukan pelatihan sehingga setiap karyawan selalu memiliki kemampuan untuk mengembangkan diri. (f) Perencanaan dan Pengembangan karir: untuk proses pengambilan keputusan utamanya tentang karir spesifik dari karyawan sebagai tahapan untuk 
pengembangan diri. (g) Evaluasi proses staffing: untuk mengetahui kekuatan dan kelemahan dalam prosedur penempatan staf di Departemen SDM. (h) Defisiensi proses penempatan karyawan. (i) Ketidakakuratan informasi: untuk mengetahui adanya kesalahan dalam informasi analisis pekerjaan, perencanaan SDM, atau hal lain dari sistem SDM. (j) Kesalahan dan merancang pekerjaan: untuk mengetahui kesalahan. (k) Kesempatan kerja yang adil: untuk menjamin bahwa keputusan penempatan internal bukanlah merupakan sesuatu yang diskriminatif. (1) Mengatasi tantangan-tantangan eksternal: untuk mengetahui pengaruh faktor eksternal seperti keluarga, finansial, kesehatan ataupun masalah-masalah lainnya terhadap kinerjanya. (m) Elemen-elemen pokok sistem penilaian kinerja. (n) Umpan balik ke Sumber Daya Manusia, untuk mengetahui kinerja fungsi departemen Sumber Daya Manusia.

Dimensi atau indikator kinerja merupakan aspek-aspek yang menjadi ukuran dalam menilai kinerja. Dimensi dan indikator dijadikan tolak ukur dalam menilai kinerja dan akan sangat diperlukan karena bermanfaat baik bagi banyak pihak. Menurut John Miner dalam Sudarmanto (2015:11) mengemukakan bahwa dimensi dari kinerja yaitu: (a) Kualitas yaitu: menerangkan tentang jumlah kesalahan, kerusakan, kecermatan. (b) Kuantitas yaitu: jumlah pekerjaan yang dihasilkan berkenaan. (c) Waktu kerja yaitu: menerangkan tingkat kehadiran, keterlambatan, waktu kerja efektif. (d) Kerjasama dalam orang lain dalam bekerja.

\section{Kompensasi dan Kinerja}

Salah satu cara manajemen untuk meningkatkan prestasi kerja, motivasi dan meningkatkan kepuasan atas hasil kerja karyawan adalah melalui kompensasi (Mathis dan Jakson, 2000). Secara sederhana kompensasi merupakan sesuatu yang diterima karyawan untuk balas jasa kerja mereka. Simamora (2004) mengatakan bahwa kompensasi dalam bentuk finansial atau kompensasi langsung adalah penting bagi karyawan, sebab dengan kompensasi ini mereka dapat memenuhi kebutuhannya secara langsung, terutama kebutuhan fisiologisnya. Namun demikian, tentunya karyawan juga berharap agar kompensasi yang diterimanya sesuai dengan pengorbanan yang telah diberikan. Kompensasi dalam bentuk non finansial atau tidak langsung juga sangat penting bagi karyawan terutama untuk pengembangan karir mereka.

Pemberian kompensasi sangat penting bagi setiap karyawan dan berguna bagi perusahaan untuk menetapkan tindakan kebijaksanaan dan upaya meningkatkan kinerja. Eddy Sutrisno (2011:181) mengatakan bahwa kompensasi merupakan fungsi yang paling penting dalam manajemen sumber daya manusia (MSDM), karena kompensasi merupakan salah satu aspek yang paling sensitif didalam hubungan kerja. Pengertian di atas terlihat bahwa kompensasi merupakan alat pengikat yang digunakan oleh perusahaan terhadap karyawannya. Kompensasi merupakan faktor penarik bagi calon karyawan dan faktor pendorong seseorang menjadi karyawan. Dengan demikian, kompensasi mempunyai fungsi yang cukup penting dalam memperlancar jalannya roda organisasi/perusahaan.

Kinerja merupakan hasil dari kerja para karyawan yang dilakukan dengan batas waktu tertentu. John Miner dalam Sudarmanto (2015:8) mengatakan bahwa 
kinerja merupakan produktivitas hubungan antara jumlah barang dan jasa yang dihasilkan dengan jumlah tenaga kerja, modal dan sumber daya yang digunakan dalam produksi itu. Kinerja dapat diukur melalui indikator-indikatornya seperti pengetahuan, prakarsa dan dedikasi kerja, keterampilan, hubungan antar manusia dan kejujuran. Kinerja yang dimaksud oleh peneliti adalah kinerja karyawan yang diukur oleh beberapa unsur yaitu pengetahuan karyawan tentang produk dan tugas-tugasnya, keterampilan karyawan dalam memberikan pelayanan kepada konsumen dan keterampilan untuk memajukan perusahaan, hubungan antar manusia yaitu kemampuan karyawan untuk menjalin kerjasama baik sesama rekan-kerja maupun atasan atau bawahannya, prakarsa dan dedikasi kerja yang diwujudkan dengan kesungguhan dalam melaksanakan pekerjaan dan kejujuran adalah kemampuan karyawan untuk berlaku jujur terhadap hak dan kewajibannya dalam menjalankan tugas-tugasnya (Winardi, 2000:128). Salah satu cara terbaik untuk meningkatkan kualitas kinerja karyawan adalah dengan menghubungkan kompensasi dengan kinerja karyawan.

Meskipun kompensasi merupakan elemen penting, tapi kompensasi bukanlah sebuah tujuan, melainkan hanya sebagai alat (tools) untuk mencapai atau memengaruhi tujuan itu sendiri. Oleh karena itu dalam penelitian ini kompensasi tidak ditempatkan sebagai isu sentral atau sebagai variabel terikat (dependent), melainkan pada posisi yang memengaruhi atau varibel bebas (independent) (Edison dkk, 2016 hal. 156). Walaupun dalam beberapa penelitian kerap menempatkan kinerja sebagai isu sentral dan ditempatkan sebagai variabel terikat (dependent variables). Keberhasilan kinerja ini sangat dipengaruhi beberapa variabel lainnya sebagai variabel bebas (independent variables), seperti kepemimpinan, budaya organisasi, kompensasi, komitmen dan kompetensi"(Ibid, hal. 197)

\section{METODE PENELITIAN}

\section{Metode, Variabel dan Lokasi Penelitian}

Penelitian ini menggunakan metode Kuantitatif dengan analisis regresi berganda. Objek dalam penelitian ini terdiri dari tiga variabel, yaitu variabel bebas dan variabel terikat. Variabel bebas terdiri dari Variabel Kompensasi Langsung $\left(\mathrm{X}_{1}\right)$ dan Kompensasi Tidak Langsung $\left(\mathrm{X}_{2}\right)$, sementara Variabel terikat yaitu Kinerja Karyawan(Y). Lokasi penelitian dilakukan di Kampung Batu Malakasari Tektona Waterpark Kabupaten Bandung. Sifat penelitian menggunakan analisis deskriptif dan verifikatif. Penelitian deskriptif bertujuan untuk membuat penelitian atau gambaran secara sistematis, faktual, akurat, mengenai sifat-sifat serta hubungan antar variabel yang diteliti. Sedangkan analisis verifikatif bertujuan untuk menguji hubungan antar variabel dengan menggunakan analisis statistik. Jumlah responden sebanyak 30 orang karyawan yaitu seluruh populasi yang ada, jadi seluruh populasi dijadikan sampel penelitian karena subyek penelitian kurang dari 100 orang. 


\section{Operasional Variabel}

Agar variabel dapat diterjemahkan ke dalam bentuk kuesioner maka perlu diterjemahkan ke dalam operasional variabel sebagaimana diungkapkan Emron Edison, dkk. (2016:103): "Variabel-variabel yang sudah ditetapkan sebagai variabel penelitian, perlu didefinisikan secara operasional agar menjadi faktor-faktor yang dapat diukur dan diketahui nilainya, hal ini terkait dengan sampel penelitian. Sederhananya, operasional variabel membimbing peneliti menterjemahkan variabel penelitian menjadi kuesioner penelitian".

Tabel 1

\section{Operasional Variabel}

\begin{tabular}{|c|c|c|c|c|c|}
\hline No & Variabel & Konsep & Indikator & Ukuran & Skala \\
\hline \multirow[t]{2}{*}{1.} & \multirow{2}{*}{$\begin{array}{l}\text { Kompensa } \\
\text { si } \\
\text { Langsung } \\
\text { (X1) }\end{array}$} & \multirow{2}{*}{$\begin{array}{l}\text { Kompensasi adalah segala } \\
\text { sesuatu yang diterima oleh } \\
\text { karyawan sebagai balas } \\
\text { jasa untuk kerja mereka } \\
\text { (Handoko dalam Eddy } \\
\text { Sutrisno,2011 hal. 183) }\end{array}$} & Gaji & $\begin{array}{l}\text { Tingkat } \\
\text { pembayaran secara } \\
\text { periodic }\end{array}$ & Ordinal \\
\hline & & & Insentif & $\begin{array}{l}\text { Tingkat } \\
\text { kesesuaian insentif } \\
\text { dengan pekerjaan }\end{array}$ & Ordinal \\
\hline \multirow[t]{5}{*}{2.} & \multirow[t]{5}{*}{$\begin{array}{l}\text { Kompensa } \\
\text { si Tidak } \\
\text { Langsung } \\
(\mathrm{X} 2)\end{array}$} & & $\begin{array}{l}\text { Asuransi } \\
\text { Kesehatan }\end{array}$ & $\begin{array}{l}\text { Tingkat } \\
\text { terpenuhinya } \\
\text { Asuransi } \\
\text { Kesehatan }\end{array}$ & Ordinal \\
\hline & & & $\begin{array}{l}\text { Tunjangan } \\
\text { Transport }\end{array}$ & $\begin{array}{l}\text { Tingkat } \\
\text { Terpenuhinya } \\
\text { Tunjangan } \\
\text { Transport }\end{array}$ & Ordinal \\
\hline & & & $\begin{array}{l}\text { Tunjangan } \\
\text { Cuti }\end{array}$ & $\begin{array}{l}\text { Tingkat } \\
\text { Terpenuhinya } \\
\text { Tunjangan Cuti }\end{array}$ & Ordinal \\
\hline & & & $\begin{array}{l}\text { Tunjangan } \\
\text { Rekreasi }\end{array}$ & $\begin{array}{l}\text { Tingkat } \\
\text { Terpenuhinya } \\
\text { Tunjangan } \\
\text { Rekreasi }\end{array}$ & Ordinal \\
\hline & & & $\begin{array}{l}\text { Tunjangan } \\
\text { Hari Raya }\end{array}$ & $\begin{array}{l}\text { Tingkat } \\
\text { Terpenuhinya } \\
\text { Tunjangan Hari } \\
\text { raya }\end{array}$ & Ordinal \\
\hline
\end{tabular}




\begin{tabular}{|c|c|c|c|c|c|}
\hline & $\begin{array}{l}\text { Kinerja } \\
\text { Karyawan } \\
(Y)\end{array}$ & \multirow{4}{*}{$\begin{array}{l}\text { Kinerja merupakan } \\
\text { produktivitas hubungan } \\
\text { antara jumlah barang dan } \\
\text { jasa yang dihasilkan } \\
\text { dengan jumlah tenaga } \\
\text { kerja, modal, dan sumber } \\
\text { daya yang digunakan } \\
\text { dalam produksi itu. John } \\
\text { Miner dalam (Sudarmanto, } \\
2015 \text { hal. 11) }\end{array}$} & Kualitas & $\begin{array}{l}\text { Tingkat } \\
\text { kesesuaian } \\
\text { kualitas dengan } \\
\text { prosedur }\end{array}$ & Ordinal \\
\hline & & & Kuantitas & $\begin{array}{l}\text { Tingkat kejelasan } \\
\text { prosedur terhadap } \\
\text { kualitas }\end{array}$ & Ordinal \\
\hline & & & $\begin{array}{l}\text { Waktu } \\
\text { Kerja }\end{array}$ & $\begin{array}{l}\text { Kuantitas hasil } \\
\text { pekerjaan sesuai } \\
\text { yang dengan } \\
\text { waktu }\end{array}$ & Ordinal \\
\hline & & & $\begin{array}{l}\text { Kerja } \\
\text { Sama }\end{array}$ & $\begin{array}{l}\text { Tingkat kerja } \\
\text { sama dalam } \\
\text { bekerja }\end{array}$ & Ordinal \\
\hline
\end{tabular}

Sumber: Pengolahan Data Penelitian

\section{Pengujian Instrumen}

Pengujian instrumen untuk metode kuantitatif dengan cara uji validitas, uji realibilitas/uji keandalan alat ukur, "Setelah data hasil kuesioner diperoleh, maka data tersebut dianalisis apakah data kuesioner tersebut adalah data yang tepat (valid), andal (reliable), dan konsisten (internal consistency). Untuk semua itu dilakukan pengujian validitas dan reliabilias instrument pengajuan validitas instrumen dilakukan dengan menggunakan rumus Correlation Product Momentll (Sugiono, 2001:182).

Pengujian instrumen juga dilakukan dengan cara uji normalitas data dan uji konversi data. Sebelum data diolah terlebih dahulu dilakukan uji normalitas. Uji normalitas digunakan untuk mengetahui apakah suatu data mengikuti sebaran normal atau tidak. Untuk mengetahui apakah data tersebut mengikuti sebaran normal dapat dilakukan dengan berbagai metode diantaranya adalah metode kolmogorov smirnov dan metode shapiro wilk.

Pengujian normalitas berdasarkan pada uji Kolmogorov-Smirnov, adapun hipotesis yang diuji adalah:

$$
\begin{aligned}
& \mathrm{H}_{0}: \rho \text {-value }> \\
& 0.05 \\
& \mathrm{H}_{1}: \rho \text {-value }> \\
& 0.05
\end{aligned}
$$

Sampel tidak berasal dari populasi yang berdistribusi normal.

Sampel berasal dari populasi yang berdistribusi normal

Kuesioner penelitian dirancang dengan menggunakan skala ordinal. —Data yang terkumpul melalui kuesioner ini adalah data yang berskala ordinal, 
sedangkan peringkat data untuk dapat digunakan dalam statistika inferensial (analisis jalur), yang digunakan dalam pengujian hipotesis penelitian ini adalah peringkat data interval. Oleh karena itu, data tersebut terlebih dahulu dilakukan konversi dari skala ordinal ke skala interval. Teknik yang digunakan adalah metode interval berurutan (methods of successive interval)ll (Hays, dalam AlRassyid, 1994).

Untuk mengukur tingkat penafsiran menurut J. Supranto (2001) sebagai berikut: 4,2 -5,0 sangat baik, 3,4 -4,1 baik, 2,6-3,3 cukup baik, 1,8 -2,5 kurang baik, 1,0 -1,7 sangat tidak baik.

\section{HASIL DAN PEMBAHASAN}

1. Hasil Uji Instrumen

a) Hasil Uji Validitas

Tabel 2

Hasil Uji Validitas Variabel X1

\begin{tabular}{|l|c|c|c|c|}
\hline Variabel & $\begin{array}{c}\text { Item } \\
\text { Pernyataan }\end{array}$ & $\begin{array}{c}\text { Koefisien } \\
\text { Validitas }\end{array}$ & $\begin{array}{c}\text { Titik } \\
\text { Kritis }\end{array}$ & Ket \\
\hline \multirow{4}{*}{$\begin{array}{l}\text { Kompensasi } \\
\text { Langsung } \\
\left(X_{1}\right)\end{array}$} & $\mathrm{X} 1-1$ & 0,656 & 0,300 & Valid \\
\cline { 2 - 5 } & $\mathrm{X} 1-2$ & 0,402 & 0,300 & Valid \\
\cline { 2 - 5 } & $\mathrm{X} 1-3$ & 0,439 & 0,300 & Valid \\
\cline { 2 - 5 } & $\mathrm{X} 1-5$ & 0,506 & 0,300 & Valid \\
\cline { 2 - 5 } & $\mathrm{X} 1-6$ & 0,473 & 0,300 & Valid \\
\hline
\end{tabular}

Sumber: Pengolahan Data Penelitian

Tabel 3

Hasil Uji Validitas Variabel X2

\begin{tabular}{|l|c|c|c|c|}
\hline \multirow{4}{*}{ Variabel } & $\begin{array}{c}\text { Item } \\
\text { Pernyataan }\end{array}$ & $\begin{array}{c}\text { Koefisien } \\
\text { Validitas }\end{array}$ & $\begin{array}{c}\text { Titik } \\
\text { Kritis }\end{array}$ & Ket \\
\hline \multirow{2}{*}{$\begin{array}{l}\text { Kompensasi } \\
\text { Tidak } \\
\text { Langsung } \\
\left(X_{2}\right)\end{array}$} & $\mathrm{X} 2-1$ & 0,380 & 0,300 & Valid \\
\cline { 2 - 5 } & $\mathrm{X} 2-2$ & 0,604 & 0,300 & Valid \\
\cline { 2 - 5 } & $\mathrm{X} 2-4$ & 0,408 & 0,300 & Valid \\
\cline { 2 - 5 } & $\mathrm{X} 2-5$ & 0,600 & 0,300 & Valid \\
\hline
\end{tabular}

Sumber: Pengolahan Data Penelitian 


\begin{tabular}{|l|c|r|r|c|}
\hline & X2-6 & 0,750 & 0,300 & Valid \\
\hline
\end{tabular}

Tabel 4

Hasil Uji Validitas Variabel Y

\begin{tabular}{|c|c|c|c|c|}
\hline Variabel & $\begin{array}{c}\text { Item } \\
\text { Pernyataan }\end{array}$ & $\begin{array}{c}\text { Koefisien } \\
\text { Validitas }\end{array}$ & $\begin{array}{c}\text { Titik } \\
\text { Kritis }\end{array}$ & Ket \\
\hline \multirow{4}{*}{} & Y1 & 0,562 & 0,300 & Valid \\
\cline { 2 - 5 } & Y2 & 0,472 & 0,300 & Valid \\
\cline { 2 - 5 } & Y3 & 0,663 & 0,300 & Valid \\
\cline { 2 - 5 } & Y4 & 0,683 & 0,300 & Valid \\
\cline { 2 - 5 } & Y5 & 0,524 & 0,300 & Valid \\
\cline { 2 - 5 } & Y6 & 0,602 & 0,300 & Valid \\
\cline { 2 - 5 } & Y7 & 0,711 & 0,300 & Valid \\
\cline { 2 - 5 } & Y8 & 0,514 & 0,300 & Valid \\
\cline { 2 - 5 } & Y9 & 0,649 & 0,300 & Valid \\
\cline { 2 - 5 } & Y10 & 0,518 & 0,300 & Valid \\
\cline { 2 - 5 } & Y11 & 0,664 & 0,300 & Valid \\
\cline { 2 - 5 } & Y12 & 0,586 & 0,300 & Valid \\
\cline { 2 - 5 } & & & &
\end{tabular}

Sumber: Pengolahan Data Penelitian

Berdasarkan hasil uji validitas terhadap semua pernyataan (kuesioner) untuk variabel $\mathrm{X}_{1}, \mathrm{X}_{2}$ dan Ydinyatakan valid karena Koefisien Validitas diatas 0,300

b) Hasil Uji Realibilitas

Tabel 5

Hasil Uji Reliabiltas

\begin{tabular}{|c|l|c|c|c|}
\hline No & \multicolumn{1}{|c|}{ Variabel } & $\begin{array}{c}\text { Koefisien } \\
\text { Realibilitas }\end{array}$ & $\begin{array}{c}\text { Titik } \\
\text { Kritis }\end{array}$ & Ketetangan \\
\hline 1. & $\begin{array}{l}\text { Kompensasi } \\
\text { Langsung (X1) }\end{array}$ & 0,780 & 0,700 & Reliabel \\
\hline
\end{tabular}




\begin{tabular}{|c|l|c|c|c|}
\hline 2. & $\begin{array}{l}\text { Kompensasi tidak } \\
\text { Langsung (X2) }\end{array}$ & 0,780 & 0,700 & Reliabel \\
\hline 3. & Kompensasi & 0,771 & 0,700 & Reliabel \\
\hline
\end{tabular}

Sumber: Pengolahan Data Penelitian

Berdasarkan tabel diatas maka semua vaiabel $\left(\mathrm{X}_{1}, \mathrm{X}_{2}\right.$ dan $\left.\mathrm{Y}\right)$ realibel, karena $\mathrm{r}$ kritis sebesar 0,700. Artinya bahwa keseluruhan butir pertanyaan data diatas dinyatakan valid.

\section{Hasil Penelitian}

Hasil penelitian adalah untuk menjawab rumusan masalah yang ada dalam Bab 1. Hasil penelitan diuraikan sebagai berikut:

a) Gambaran Tentang Kompensasi Langsung ( $\mathrm{X}_{1}$ ) di Kampung Batu Malakasari

Hasil penelitian mengenai gambaran kompensasi langsung $\left(\mathrm{X}_{1}\right)$, merupakan analisis deskriftif yang diuraikan per dimensi.

Tabel 6

Rekapitulasi Kuesioner tentang Kompensasi Langsung

\begin{tabular}{|c|c|c|c|c|c|c|c|c|}
\hline \multirow{2}{*}{ No } & \multirow{2}{*}{ Pernyataan } & \multicolumn{5}{|c|}{$\begin{array}{c}\text { Alternatif } \\
\text { Jawaban }\end{array}$} & \multirow{2}{*}{$\begin{array}{l}\text { Jumlah } \\
\text { Skor }\end{array}$} & \multirow{2}{*}{ Keterangan } \\
\hline & & 5 & 4 & 3 & 2 & 1 & & \\
\hline 1 & $\begin{array}{l}\text { Gaji diberikan tepat waktu } \\
\text { sesuai dengan jadwal yang } \\
\text { telah disepakati dengan } \\
\text { pihak perusahaan }\end{array}$ & 4 & 10 & 12 & 4 & 0 & 104 & 3,47 \\
\hline 2 & $\begin{array}{l}\text { Gaji yang diberikan dapat } \\
\text { mencukupi kebutuhan } \\
\text { keluarga }\end{array}$ & 11 & 12 & 6 & 1 & 0 & 123 & 4,10 \\
\hline 3 & $\begin{array}{l}\text { Gaji yang diberikan } \\
\text { perusahaan tempat saya } \\
\text { bekerja selama ini dapat } \\
\text { meningkatkan semangat } \\
\text { dalam bekerja }\end{array}$ & 8 & 12 & 10 & 0 & 0 & 118 & 3,93 \\
\hline 4 & $\begin{array}{l}\text { Gaji yang diterima telah } \\
\text { sesuai dengan prestasi kerja } \\
\text { karyawan }\end{array}$ & 11 & 10 & 7 & 2 & 0 & 120 & 4.00 \\
\hline
\end{tabular}




\begin{tabular}{|c|l|r|r|r|r|r|r|c|}
\hline 5 & $\begin{array}{l}\text { Karyawan mendapatkan } \\
\text { insentif setiap tahun dari } \\
\text { perusahaan }\end{array}$ & 4 & 14 & 12 & 0 & 0 & 112 & 3,73 \\
\hline 6 & $\begin{array}{l}\text { Karyawan menerima upah } \\
\text { insentif sesuai dengan yang } \\
\text { diharapkan }\end{array}$ & 5 & 17 & 6 & 2 & 0 & 115 & 3,83 \\
\hline \multicolumn{6}{|c|}{ Jumlah Skor } \\
\hline
\end{tabular}

Sumber : Pengolahan Data Penelitian

Berdasarkan Tabel 6 di atas, kompensasi langsung rata-rata 3,85 dalam kategori baik. Jika dilihat dari penilaian tertinggi adalah pernyataan - gaji yang diberikan dapat mencukupi kebutuhan keluargall dengan skor rata-rata 4,10. Hal tersebut terjadi karena gaji yang berikan setiap bulannya sudah mencukupi kebutuhan sehari-hari.

Sedangkan penilaian terendah adalah pernyataan Gaji yang diberikan tepat waktu sesuai dengan jadwal yang telah disepakatill dengan total skor 3,47. Hal ini terjadi karena pemberian gaji seringkali mengalami keterlambatan akan tetapi masih dalam kategori baik.

\section{b) Gambaran Tentang Kompensasi Tidak Langsung (X2) di Kampung Batu Malakasari}

Hasil penelitian mengenai gambaran kompensasi tidak langsung $\left(\mathrm{X}_{2}\right)$, merupakan analisis deskriftif sebagai berikut:

\section{Tabel 7}

Tanggapan Responden Mengenai Kompensasi Tidak Langsung( $\left.\mathrm{X}_{2}\right)$

\begin{tabular}{|c|c|c|c|c|c|c|c|c|}
\hline \multirow{2}{*}{ No } & \multirow{2}{*}{ Pernyataan } & \multicolumn{5}{|c|}{$\begin{array}{c}\text { Alternatif } \\
\text { Jawaban }\end{array}$} & \multirow{2}{*}{$\begin{array}{c}\text { Jumlah } \\
\text { Skor }\end{array}$} & \multirow{2}{*}{ Keterangan } \\
\hline & & 5 & 4 & 3 & 2 & 1 & & \\
\hline 1 & $\begin{array}{l}\text { Karyawan diberikan asuransi } \\
\text { kesehatan oleh perusahaan }\end{array}$ & 7 & 10 & 9 & 4 & 0 & 110 & 3,67 \\
\hline 2 & $\begin{array}{l}\text { Karyawan tidak pernah } \\
\text { khawatir menghadapi } \\
\text { masalah kesehatan, karena } \\
\text { Kampung Batu Malakasari } \\
\text { memiliki jaminan kesehatan }\end{array}$ & 7 & 10 & 11 & 2 & 0 & 112 & 3,73 \\
\hline
\end{tabular}




\begin{tabular}{|c|l|r|r|r|r|r|r|c|}
\hline 3 & $\begin{array}{l}\text { Perusahaan selalu } \\
\text { memberikan Tunjangan Hari } \\
\text { Raya (THR) }\end{array}$ & 12 & 9 & 9 & 0 & 0 & 123 & 4,10 \\
\hline 4 & $\begin{array}{l}\text { Karyawan mendapatkan hak } \\
\text { cuti sesuai dengan peraturan } \\
\text { perusahaan }\end{array}$ & 4 & 15 & 6 & 5 & 0 & 108 & 3,60 \\
\hline 5 & $\begin{array}{l}\text { Rekreasi di selenggarakan } \\
\text { minimal satu kali dalam } \\
\text { setahun }\end{array}$ & 9 & 13 & 8 & 0 & 0 & 121 & 4,03 \\
\hline 6 & $\begin{array}{l}\text { Perusahaan memberikan } \\
\text { tunjangan transport secara } \\
\text { rutin }\end{array}$ & 10 & 19 & 1 & 0 & 0 & 129 & 4,30 \\
\hline
\end{tabular}

Sumber : Pengolahan Data Penelitian

Berdasarkan tabel $7 \mathrm{di}$ atas, kompensasi tidak langsung rata-rata 3,91 dengan penilaian dalam kategori baik. Jika dilihat dari penilaian tertinggi adalah pernyataan -Perusahaan memberikan tunjangan transport secara rutinll dengan skor rata-rata 4,30. Sedangkan, penilaian terendah dari kompensasi tidak langsung adalah pernyataan Karyawan mendapatkan hak cuti sesuai dengan peraturan perusahaanll dengan rata-rata skor 3,60. Hal ini terjadi karena perusahaan tidak memberikan cuti dalam jangka waktu tertentu. Akan tetapi secara penilaian juga masih dalam kondisi baik.

Rekapitulasi mengenai hasil tanggapan kompensasi langsung dan kompensasi tidak langsung terhadap kinerja karyawan Kampung Batu Malakasari Tektona Waterpark Kabupaten Bandung dapat dilihat dari tabel 8 yang disajikan sebagai berikut:

Tabel 8

\section{Rekapitulasi Hasil Tanggapan Kompensasi Langsung dan Kompensasi Tidak Langsung di Kampung Batu Malakasari Kabupaten Bandung}

\begin{tabular}{|c|l|c|c|c|}
\hline No & Sub Variabel & Total Skor & Skor Rata-rata & $\%$ \\
\hline 1 & Kompensasi Langsung & 692 & 115.33 & 49.60 \\
\hline 2 & Kompensasi Tidak Langsung & 703 & 117.167 & 50.39 \\
\hline & Total & 1395 & 232.497 & 100 \\
\hline
\end{tabular}

Sumber : Pengolahan Data Penelitian 


\section{c) Gambaran Tentang Kinerja Karyawan (Y) di Kampung Batu Malakasari}

Hasil penelitian mengenai gambaran kinerja karyawan (Y), merupakan analisis deskriftif yang diuraikan per dimensi sebagai berikut:

\section{(1) Dimensi Kualitas}

Tabel 9

Tanggapan Responden Mengenai dimensi Kualitas dari variabel $Y$

\begin{tabular}{|c|c|c|c|c|c|c|c|c|}
\hline \multirow{2}{*}{ No } & \multirow{2}{*}{ Pernyataan } & \multicolumn{5}{|c|}{$\begin{array}{l}\text { Alternatif } \\
\text { Jawaban }\end{array}$} & \multirow{2}{*}{$\begin{array}{c}\text { Jumlah } \\
\text { Skor }\end{array}$} & \multirow[t]{2}{*}{ Keterangan } \\
\hline & & 5 & 4 & 3 & 2 & 1 & & \\
\hline 1 & $\begin{array}{l}\text { Kualitas yang saya hasilkan } \\
\text { sesuai dengan standar yang } \\
\text { sudah ditetapkan }\end{array}$ & 1 & 17 & 12 & 0 & 0 & 109 & 3,63 \\
\hline 2 & $\begin{array}{l}\text { Bagi karyawan, kualitas adalah } \\
\text { mutlak untuk dipenuhi }\end{array}$ & 4 & 17 & 9 & 0 & 0 & 115 & 3,83 \\
\hline 3 & $\begin{array}{l}\text { Untuk memenuhi kualitas yang } \\
\text { baik, karyawan selalu bekerja } \\
\text { berdasarkan prosedur-prosedur } \\
\text { yang ada }\end{array}$ & 2 & 13 & 15 & 0 & 0 & 107 & 3,57 \\
\hline \multicolumn{7}{|c|}{ Jumlah Skor Total } & 331 & \\
\hline \multicolumn{7}{|c|}{ Rerata } & & 3,68 \\
\hline
\end{tabular}

Sumber : Pengolahan Data Penelitian

Berdasarkan tabel 9 tersebut, penilaian tertinggi dari dimensi kualitas adalah kualitas mutlak untuk dipenuhi dengan rata-rata skor 3,83. Sedangkan penilaian terendah dari dimensi kualitas adalah karyawan selalu bekerja pada prosedur-prosedur yang adall dengan rata-ratal skor 3,57. Hal ini terjadi karena karyawan kurang memperhatikan prosedur-prosedur yang ada meskipun pada dasarnya dalam kategori baik.

\section{Tabel 10}

Tanggapan Responden Mengenai Kuantitas Dari DimensiY2

\begin{tabular}{|l|l|r|r|r|r|r|l|l|}
\hline & \multirow{3}{*}{ No } & Pernyataan & \multicolumn{4}{|c|}{$\begin{array}{c}\text { Alternatif } \\
\text { Jawaban }\end{array}$} & \multirow{2}{*}{$\begin{array}{c}\text { Jumlah } \\
\text { Skor }\end{array}$} & \\
\cline { 3 - 6 } & & 5 & 4 & 3 & 2 & 1 & & \\
\hline
\end{tabular}




\begin{tabular}{|r|l|r|r|r|r|r|r|r|}
\hline 1 & $\begin{array}{l}\text { Tingkat pencapaian } \\
\text { volume kerja yang saya } \\
\text { hasilkan telah sesuai } \\
\text { dengan harapan } \\
\text { perusahaan }\end{array}$ & 4 & 17 & 9 & 0 & 0 & 115 & 3,83 \\
\hline 2 & $\begin{array}{l}\text { Perusahaan menetapkan } \\
\text { target kerja dengan } \\
\text { penuh perhitungan }\end{array}$ & 3 & 18 & 9 & 0 & 0 & 114 & 3,80 \\
\hline 3 & $\begin{array}{l}\text { Karyawan dapat } \\
\text { menyelesaikan } \\
\text { pekerjaan tepat waktu }\end{array}$ & 9 & 14 & 7 & 0 & 0 & 122 & 4,07 \\
\hline \\
Jumlah Skor Total \\
\hline
\end{tabular}

Sumber : Pengolahan Data 2016

Berdasarkan tabel 10 penilaian tertinggi dari dimensi kuantitas adalah menyelesaikan pekerjaan dengan tepat waktu dengan total skor 122. Hal ini terjadi karena karyawan di Kampung Batu harus bertanggung jawab terhadap pekerjaan di bidangnya masing-masing. Penilaian terendah dari dimensi kuantitas adalah perusahaan menetapkan target kerja dengan penuh perhitungan dengan total skor 114. Hal ini terjadi karena perusahaan kurang memperhatikan target. Secara ideal, skor yang diharapkan untuk jawaban responden terhadap tiga pertanyaan adalah 450. Dari perhitungan dalam tabel menunjukkan nilai yang diperoleh 351 dari score ideal yaitu 450. Walaupun demikian kuantitas kerja berada masih berada pada kategori baik.

Tabel 11

Tanggapan Responden Mengenai Waktu Kerja Dari DimensiY3

\begin{tabular}{|c|c|c|c|c|c|c|c|c|}
\hline \multirow{2}{*}{ No } & \multirow{2}{*}{ Pernyataan } & \multicolumn{5}{|c|}{$\begin{array}{l}\text { Alternatif } \\
\text { Jawaban }\end{array}$} & \multirow{2}{*}{$\begin{array}{c}\text { Jumlah } \\
\text { Skor }\end{array}$} & \multirow{2}{*}{ Keterangan } \\
\hline & & 5 & 4 & 3 & 2 & 1 & & \\
\hline 1 & $\begin{array}{l}\text { Bagi karyawan, } \\
\text { penyelesaian kerja } \\
\text { tepat waktu itu penting } \\
\text { dan harus dicapai }\end{array}$ & 11 & 11 & 8 & 0 & 0 & 123 & 4,10 \\
\hline
\end{tabular}




\begin{tabular}{|c|c|c|c|c|c|c|c|c|}
\hline 2 & $\begin{array}{l}\text { Karyawan memberikan } \\
\text { dorongan bagi rekan } \\
\text { kerja untuk lebih giat } \\
\text { lagi }\end{array}$ & 3 & 15 & 12 & 0 & 0 & 111 & 3,70 \\
\hline 3 & $\begin{array}{l}\text { Tingkat kehadiran } \\
\text { karyawan memenuhi } \\
\text { standar yang } \\
\text { ditetapkan perusahaan }\end{array}$ & 9 & 11 & 10 & 0 & 0 & 119 & 3,97 \\
\hline \multicolumn{6}{|c|}{ Jumlah Skor } & & 353 & \\
\hline \multicolumn{6}{|c|}{ Rerata } & & & 3,92 \\
\hline
\end{tabular}

Sumber : Pengolahan Data Penelitian

Nilai tertinggi adalah 450. Dari perhitungan dalam tabel 11 nilai yang diperoleh 353. Dengan demikian jika dilihat per dimensi, maka dimensi waktu kerja berada pada kategori baik. Khususnya untuk pernyataan kuesioner "penyelesaian kerja tepat waktu" total skor 12 yaitu dalam katagori baik, hal ini terjadi karena karyawan melakukan kerja dengan tepat waktu. Sedangkan untuk penilaian terrendah dari dimensi waktu kerja adalah untuk pernyataan karyawan memberikan dorongan bagi rekan kerjall dengan total skor 111, hal ini terjadi karena kurangnya motivasi yang diberikan karyawan sehingga karyawan kurang giat dalam melakukan pekerjaan.

Tabel 12

Tanggapan Responden Mengenai Kerja Sama Dari Dimensi Y4

\begin{tabular}{|c|c|c|c|c|c|c|c|c|}
\hline \multirow{2}{*}{ No } & \multirow{2}{*}{ Pernyataan } & \multicolumn{4}{|c|}{$\begin{array}{l}\text { Alternatif } \\
\text { Jawaban }\end{array}$} & & \multirow{2}{*}{$\begin{array}{c}\text { Jumlah } \\
\text { Skor }\end{array}$} & \multirow{2}{*}{ Keterangan } \\
\hline & & 5 & 4 & 3 & 2 & 1 & & \\
\hline 1 & $\begin{array}{l}\text { karyawan seharusnya } \\
\text { membina hubungan } \\
\text { kerjasama yang } \\
\text { harmonis, baik dengan } \\
\text { pimpinan dan sesama } \\
\text { rekan kerja }\end{array}$ & 12 & 18 & 0 & 0 & 0 & 132 & 4,40 \\
\hline
\end{tabular}




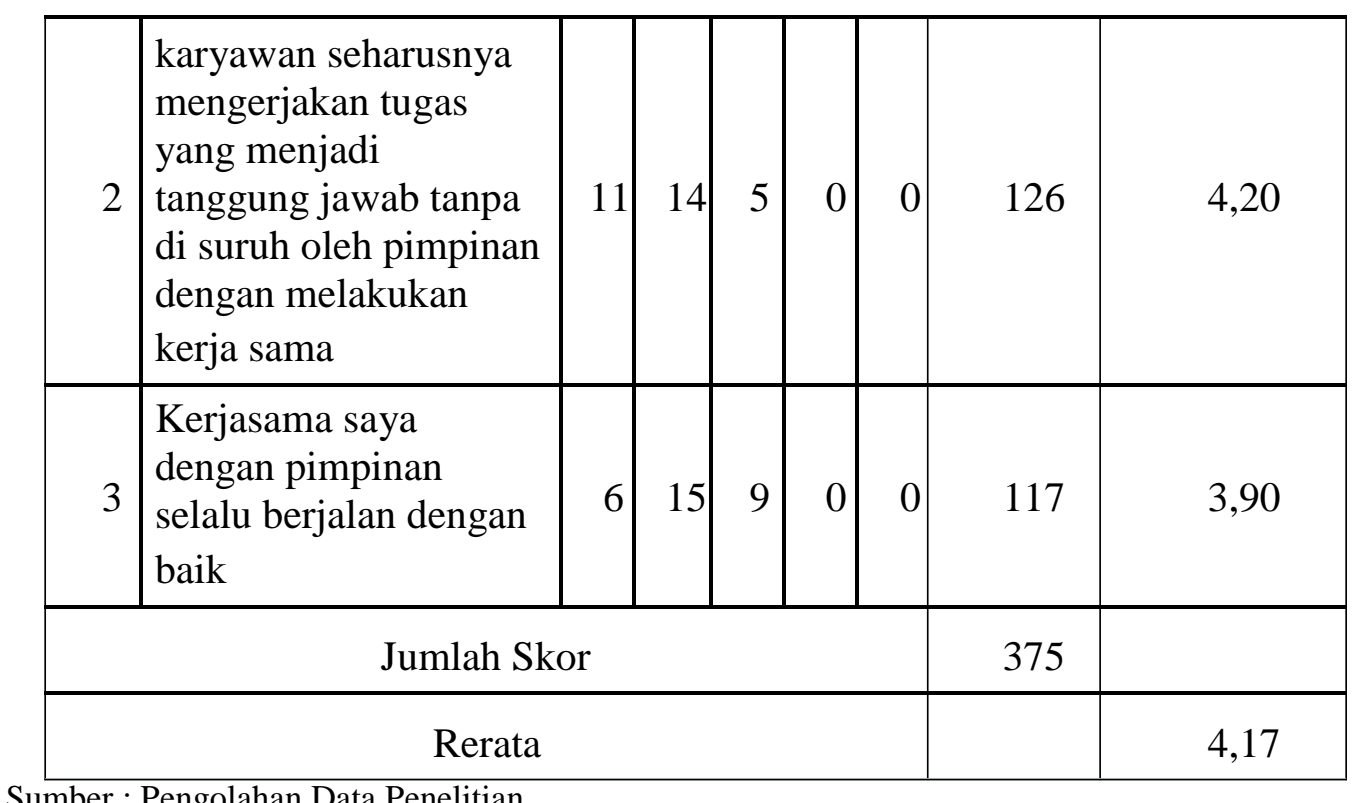

Berdasarkan tabel 12 penilaian tertinggi dari dimensi kerja sama adalah membina hubungan kerjasama yang harmonis dengan total skor 127 . Hal ini terjadi karena sangat diperlukan agar tidak ada pihak yang merasa dirugikan atas apa yang dilakukan pihak lainnya.

Secara ideal, skor yang diharapkan untuk jawaban responden terhadap tiga pertanyaan adalah 450. Dari perhitungan dalam tabel menunjukkan nilai yang diperoleh 375 dari skor ideal yaitu 450. Namun demikian kerja sama berada pada kategori baik.

\section{Rekapitulasi Hasil Tanggapan Kinerja Karyawan}

Rekapitulasi mengenai hasil tanggapan pekerja mengenai kinerja karyawan dapat dilihat dari tabel 13 yang disajikan sebagai berikut:

\section{Tabel 13}

Rekapitulasi Hasil Tanggapan Kinerja Karyawan

\begin{tabular}{|c|l|c|c|c|}
\hline No. & Sub Variabel & Total Skor & Skor Rata-rata & $\%$ \\
\hline 1 & Kualitas & 331 & 110.33 & 23.47 \\
\hline 2 & Kuantitas & 351 & 117 & 24.89 \\
\hline 3 & Waktu kerja & 353 & 117.67 & 25.04 \\
\hline 4 & Kerja sama & 375 & 125 & 26.60 \\
\hline
\end{tabular}




\begin{tabular}{|c|c|c|c|}
\hline Total & 1410 & 470 & 100 \\
\hline
\end{tabular}

Sumber: Pengolahan Data Penelitian

Berdasarkan tabel 13 diatas dapat terlihat bahwa sub variabel dari dimensi kinerja yang terdiri dari kualitas, kuantitas, waktu kerja, kerja sama yang mendapat penilaian tertinggi adalah kerja sama mendapatkan skor rata-rata 125 . Hal ini terjadi karena kerjasama yang dilakukan perusahaan kepada karyawan terjalin dengan baik sehingga apa yang dilakukan karyawan terjalin dengan kompak. Sedangkan sub variabel yang mendapatkan penilaian terendah yaitu kualitas dengan skor rata-rata 110.33, hal ini memperlihatkan bahwa kualitas harus lebih ditingkatkan lagi baik dari segi kompensasi atau kinerja.

\section{d) Pengaruh Variabel Kompensasi Terhadap Kinerja Karyawan}

Berdasarkan hasil penelitian menggunakan SPSS, maka didapat pengukuran sebagai berikut:

Tabel 14

Analisis Regresi Berganda

\section{Coefficients $^{\mathrm{a}}$}

\begin{tabular}{|c|c|c|c|c|c|}
\hline \multirow{2}{*}{ Model } & \multicolumn{2}{|c|}{$\begin{array}{l}\text { Unstandardized } \\
\text { Coefficients }\end{array}$} & $\begin{array}{l}\text { Standardized } \\
\text { Coefficients }\end{array}$ & \multirow{2}{*}{$\mathrm{t}$} & \multirow{2}{*}{ Sig. } \\
\hline & B & Std. Error & Beta & & \\
\hline 1 (Constant) & $\begin{array}{r}16.09 \\
5\end{array}$ & 4.819 & & 3.340 & .002 \\
\hline $\begin{array}{l}\text { kompensasi } \\
\text { langsung } \\
\text { (X1) }\end{array}$ & .550 & .158 & .416 & 3.491 & .000 \\
\hline $\begin{array}{l}\text { kompensasi } \\
\text { tidak } \\
\text { langsung } \\
\text { (X2) }\end{array}$ & .786 & .148 & .632 & 5.298 & .000 \\
\hline
\end{tabular}

a. Dependent Variable: kinerja karyawan

Sumber:karyawanPengolahan Data Penelitian

Persamaan regresi yang didapatkan pada tabel 14 adalah sebagai berikut:

$Y=16.095+550 X 1+786 X$ 
Dalam penelitian ini menggunakan analisis korelasi, yaitu sekumpulan metode statistik untuk mengukur derajat asosiasiataukekuatan hubungan antara dua variabel atau lebih. Didalam korelasi sederhana terdapat dua variabel yang akan dilihat hubungannya, variabel dependen dan variabel independen.

\section{Tabel 15}

\section{Hasil Perhitungan Korelasi dan Determinasi}

\begin{tabular}{|c|c|r|r|r|r|}
\hline $\begin{array}{c}\text { Mode } \\
1\end{array}$ & $\mathrm{R}$ & $\begin{array}{c}\mathrm{R} \\
\text { Square }\end{array}$ & $\begin{array}{c}\text { Adjusted R } \\
\text { Square }\end{array}$ & $\begin{array}{c}\text { Std. Error } \\
\text { of the } \\
\text { Estimate }\end{array}$ & $\begin{array}{c}\text { Durbin- } \\
\text { Watson }\end{array}$ \\
\hline 1 & $.787^{\mathrm{a}}$ & .619 & .591 & 2.12804 & 1.698 \\
\hline
\end{tabular}

a. Predictor: (Constant), kompensasi langsung dan tidak langsung

b. Dependent Variabel : kinerja karyawan Sumber: Pengolahan Data Penelitian

Berdasarkan hasil output software SPSS diatas, diperoleh nilai koefisien korelasi (R) sebesar 0.787. Hal ini menunjukkan bahwa terdapat hubungan yang sangat kuat antara kompensasi langsung (X1), kompensasi tidak langsung (X2) dan kinerja karyawan (Y).

Koefisien determinasi di atas digunakan untuk mengetahui seberapa besar pengaruh dari variabel bebas terhadap variabel terikat. Pada tabel menunjukkan menunjukkan $\mathrm{R}^{2}$ square sebesar 0.619. hal ini menunjukkan bahwa variabel kompensasi langsung dan kompensasi tidak langsung memiliki kontribusi sebesar $61.9 \%$ dan sisanya $38.1 \%$ dipengaruhi oleh faktor lain yang tidak diteliti dalam penelitian ini. hal ini menunjukkan bahwa variabel terikat mampu dijelaskan oleh variabel bebas dengan kriteria ketepatan yang tinggi.

\section{Hasil Pengujian Hipotesis}

\section{Uji F}

Uji F digunakan untuk melihat pengaruh variabel bebas secara bersamasama terhadap variabel terikat. Hasil pengujian uji $\mathrm{F}$ pada penelitian ini disajikan pada tabel 16 sebagai berikut :

Tabel 16
Hasil Uji F
\begin{tabular}{|l|c|c|c|c|c|}
\hline \multirow{3}{*}{ Model } & $\begin{array}{c}\text { Sum of } \\
\text { Squares }\end{array}$ & Df & $\begin{array}{c}\text { Mean } \\
\text { Square }\end{array}$ & F & Sig. \\
\hline
\end{tabular}




\begin{tabular}{|l|r|r|r|r|r|}
\hline $1 \quad$ Regression & 198.529 & 2 & 99.265 & 20 & $.000^{\mathrm{b}}$ \\
\hline Residual & 122.271 & 27 & 4.529 & & \\
Total & 320.800 & 29 & & & \\
\hline
\end{tabular}

a. Dependent Variable: kinerja karyawan

b. Predictors: (Constant), kompensasi tidak langsung, kompensasi langsung

Sumber : Pengolahan Data Penelitian

Hasil uji $\mathrm{F}$ yang terlihat pada tabel 16 menunjukkan tingkat signifikan di bawah $5 \%$ dan dfl $=1$ dan df $2=27$, maka didapat $F$ tabel yaitu 4,21 . Nilai dfl merupakan hasil k-1 dengan k merupakan jumlah variabel dan terikat yaitu 2.

Sedangkan df2 didapat dari $\mathrm{n}-\mathrm{k}$, dengan $\mathrm{n}$ adalah jumlah sampel yang digunakan dalam regresi yaitu 30. Hasil perhitungan IBM SPSS 22.0 nilai Fhitung $>\mathrm{F}$ tabel $21.920>4,21$ dengan demikian Ho ditolak atau HI diterima, yaitu adanya pengaruh kompensasi terhadap kinerja karyawan. Hal ini sesuai dengan teori Ghozali (2011:98), hasil uji F menunjukkan HI diterima jika $F$ hitung $>$ Ftabel sehingga dapat dikatakan bahwa variabel bebas memiliki pengaruh bersama-sama terhadap variabel terikat.

\section{Uji T}

Pengujian ini untuk melihat sejauh mana pengaruh secara sendiri-sendiri (parsial) antara variabel $\mathrm{X}$ terhadap variabel $\mathrm{Y}$, berdasarkan hasil pengolahan data dengan alat bantu program IBM SPSS 22,0 maka didapat hasil uji T, yang hasilnya seperti pada tabel 18 sebagai berikut :

Tabel 17

Hasil Uji T

\begin{tabular}{|r|r|r|}
\hline \multicolumn{1}{|c|}{ Model } & \multicolumn{1}{c|}{$\mathrm{T}$} & \multicolumn{1}{c|}{ Sig. } \\
\hline $1 \quad \begin{array}{l}\text { (Constant) } \\
\text { kompensasi langsung }\end{array}$ & 3.491 & .002 \\
$\begin{array}{l}\text { kompensasi tidak } \\
\text { langsung }\end{array}$ & 5.298 & .000 \\
\hline
\end{tabular}

Sumber : Pengolahan Data Penelitian 
Pengujian hipotesis uji t dimaksudkan untuk mengetahui hubungan linear antara variabel X secara parsial dengan variabel Y. Apakah akan menerima atau menolak hipotesis berdasarkan pada data yang diperoleh dari sampel yang diujikan. berikut:

Berdasarkan hasil perhitungan pada tabel 18, diperoleh hasil sebagai

1. Terdapat nilai signifikansi 0.00 untuk variabel $\mathrm{X} 1$ kompensasi langsung dimana nilai signifikansi lebih kecil dari nilai probabilitas 0.05 atau nilai $0.00<0.05$, maka $\mathrm{H} 1$ diterima. Jadi kompensasi langsung berpengaruh terhadap kinerja karyawan di Kampung Batu Malakasari Kabupaten Bandung.

2. Terdapat nilai signifikansi 0.00 untuk variabel X2 kompensasi tidak langsung dimana nilai signifikansi lebih kecil dari nilai probabilitas 0.05 atau nilai $0.00<0.05$, maka $\mathrm{H} 1$ diterima. Jadi kompensasi tidak langsung berpengaruh terhadap kinerja karyawan di Kampung Batu Malakasari Kabupaten Bandung.

\section{SIMPULAN}

1. Kompensasi di Kampung Batu Malakasari diberikan secara langsung dan tidak langsung. Kompensasi langsung yaitu berupa gaji dan insentif, sedangkan kompensasi tidak langsung berupa asuransi kesehatan, tunjangan transport, tunjangan cuti, tunjangan rekreasi dan tunjangan hari raya.

2. Secara keseluruhan kinerja di Kampung Batu Malakasari dikategorikan baik namun demikian dalam sub variabel kualitas harus lebih ditingkatkan lagi karena memiliki penilaian terendah.

3. Berdasarkan hasil pengujian koefisien determinasi, diperoleh nilai sebesar 0,787 dengan nilai $\mathrm{r}$ square 0,619 yang artinya kinerja dipengaruhi kompensasi sebesar $61.9 \%$ dan sisanya $38.1 \%$ dipengaruhi oleh faktor lain yang tidak diteliti dalam penelitian ini misalnya kepemimpinan, budaya organisasi, komitmen dan kompetensi.

\section{DAFTAR PUSTAKA}

Edison, E. (2016), Manajemen Sumber Daya Manusia. Bandung: Alfabeta

Ismayanti, (2011), Pengantar Pariwisata. Jakarta: PT Grasindo

Hasibuan, M. S. P. (2012), Manajemen Sumber Daya Manusia. Jakart: PT Bumi Aksara 
Mangkunegara, A. P. (2005), Evaluasi Kinerja SDM. Bandung: PT Refika Aditama

Nawawi, H. (2008), Manajemen Sumber Daya manusia. Yogyakarta: Gadjah Mada University Press

Pitana, I G. \& Diartar, I K. S. (2009). Pengantar Pariwisata, Yogyakarta: Penerbit Andi

Qureshi, Mohammed Owais. Sajjad, Syed Rumaiya. (2015). An Empirical Analysis Of The Impact Of Compensation On Job Performance And Work-Family Conflict In The Kingdom Of Saudi Arabia --A Correlation Modelll. European Scientific Journal February 2015 edition vol.11, No.4 ISSN: 1857

- 7881 (Print) e - ISSN 1857- 7431

Ridwan (2007), Skala Pengukuran Variabel-Variabel Penelitian. Bandung: Alfabeta

Rizal, Muhamad. Idrus, M.Syafiie, Djumahir, Mintarti, Rahayu. (2014). Effect of Compensation on Motivation, Organizational Commitment and Employee Performance (Studies at Local Revenue Management in Kendari City). International Journal of Business and Management Invention ISSN (Online): 2319 - 8028, ISSN (Print): 2319 - 801X

Santoso, S. (2014), Statistik Parametik. Jakarta: PT Elex Media Komputindo

Sudarmanto (2015), Kinerja dan Pengembangan Kompetensi SDM. Yogyakarta: PT Pustaka Pelajar

Sugiyono (2008), Metode Penelitian Kuantitatif, dan Kualitatif . Bandung: Alfabeta

Sutrisno, E. (2011), Manajemen Sumber Daya Manusia. Jakarta: PT Prenada Media Group

Undang-Undang Republik Indonesia Nomor 10 Tahun 2009 tentang: Kepariwisataan

Yoeti, O. A.. (2002). Perencanaan \& Pengembangan Pariwisata. Jakarta: PT Pradaya Paramita.

Ramzan, Muhammad. Zubair, Hafiz M. Kashif. Ali, Ghazanfar. Arslan, Muhammad. (2014). International Journal of Business and Social Science Vol. 5 No. 2; February 2014 
